\title{
The Role of Synthetic A Priori Propositions in the Development of Kant's Account of Practical Autonomy: A Critique of Watkins' Reading of Kant's Prolegomena
}

\author{
KONSTANTIN POLLOK \\ Johannes Gutenberg Universität Mainz \\ Email: kpollok@uni-mainz.de
}

\begin{abstract}
I draw attention to a 12-page Vorarbeit to Kant's Prolegomena from the so-called Scheffner-Nachla $\beta$ and argue that the parallel Kant draws there between the possibility of theoretical and practical synthetic a priori propositions provides important insight into the development of his account of practical autonomy in the Groundwork. Based on a brief sketch of the role synthetic a priori propositions play in the development of Kant's critical philosophy, I conclude that for Kant the objective validity of any science depends on the objective validity of a number of synthetic a priori propositions.
\end{abstract}

Keywords: categorical imperative, synthetic a priori, transcendental deduction, autonomy, legislation

Eric Watkins' recent book Kant on Laws (Watkins 20I9) is primarily concerned with laws of nature, including what he calls transcendental laws, i.e. 'a special kind of law insofar as they are based on relations among the natures of things and our nature as cognitive beings' (p. 36). The fifth and final part of the book (chapters I I and I 2), however, deals with the moral law. In chapter II, 'Autonomy and the Legislation of Laws in the Prolegomena', Watkins argues that 'the Prolegomena form ... an important part of the explanation of the emergence of autonomy in the Groundwork' (p. 228). 
After comparing and contrasting Kant's accounts of theoretical and practical legislation, Watkins asks:

Do the substantive philosophical parallels between practical autonomy and theoretical legislation that Kant envisions justify the historical claim that he was led by the development of the account of theoretical legislation in the first edition of the first Critique and the Prolegomena to develop his account of practical autonomy in the Groundwork? ... [T] here is no conclusive textual evidence that would resolve the issue. (p. 245)

In what follows I will provide textual evidence for the fact that Kant 'was led by the development of the account of theoretical legislation in the first edition of the first Critique and the Prolegomena to develop his account of practical autonomy in the Groundwork'. I will first cite a passage from the so-called Scheffner-Nachlaß which includes a I 2-page Vorarbeit to the Prolegomena, and second comment on its relevance in the present context. Here is the crucial passage:

Now, there is the question: how is a categorical imperative possible? Whoever solves this problem has found the real principle of morals. The reviewer will probably take up this task as little as he does the important problem of transcendental philosophy, which has a striking similarity with that of morals. I will before long unveil the solution, but one must not get worried about idealism and categories here. (VA-Prol, 23: 60; my translation $)^{\mathrm{I}}$

I think this is 'textual evidence' that at least in part resolves the question about the development of Kant's 'account of practical autonomy in the Groundwork'. But to see this as 'textual evidence' requires acknowledging the centrality of the question, how are synthetic judgements a priori possible? For the 'striking similarity' between the important problems of transcendental philosophy and morals is based on the possibility of synthetic a priori judgements, or so I will argue in this essay.

Watkins does not consider the bridging role that synthetic a priori propositions play in relation to theoretical and practical philosophy after the first edition of the Critique. This seems surprising since Kant takes the most fundamental laws in mathematics, natural science (including biology), metaphysics (including transcendental philosophy), ethics, political philosophy and aesthetics to be synthetic a priori propositions. 
Moreover, Kant does not think that this is self-evident but argues for his view explicitly and extensively in each of these contexts.

Historically, the prominent role of synthetic a priori propositions in Kant's philosophy - highlighted by the Marburg School of Neo-Kantians - has earned a bad reputation. One reason for this seems to be that Kant invokes them to articulate non-empirical foundations of mathematics and natural science, and so some naturalists might take them for relics of the 'Cartesian dream' (Quine I990: 19) and thus reject them. Another reason seems to be that Kant invokes them to critique traditional metaphysics, i.e. rational psychology, cosmology and theology, which is why readers of Kant's transcendental idealism with more realist inclinations might deflate their role. In this paper I will neither propose a non-naturalist reading of Kant's philosophy nor defend a transcendental idealist versus realist reading of his transcendental idealism. Instead, I will limit my analysis to the role synthetic a priori propositions play in the development of Kant's critical philosophy, including his metaphysics of morals.

The Scheffner passage illuminates that, based on an important expansion of the problem of synthetic a priori propositions, just a short time after the first Critique's publication Kant realized that the question, how can pure reason be practical?, or how can pure reason determine the will?, required closer attention. ${ }^{2}$ The passage highlights Kant's key insight that the categorical imperative, or the principle of autonomy, as he repeatedly juxtaposes these notions in the Groundwork, is a synthetic a priori proposition and therefore requires a non-empirical deduction just as much as the categories that gave rise to theoretical synthetic a priori propositions. By the same token, this passage also serves as a clue why Kant wrote a second Critique which was not on his radar in $\mathrm{I} 78 \mathrm{I}$.

The search for an answer to the question, how are synthetic judgements a priori possible? , can be seen as guiding the development of Kant's critical philosophy from the early I770s. ${ }^{3}$ In the first edition of the Critique he speaks of the problem of synthetic a priori judgements as a 'certain mystery ... the elucidation of which alone can make progress in the boundless field of pure cognition of the understanding secure and reliable: namely, to uncover the ground of the possibility of synthetic a priori judgments with appropriate generality' (Aıо). But it is not until the Prolegomena that 'synthetic propositions a priori ... alone constitute its [metaphysics'] aim', and form 'the essential content of metaphysics' $(P, 4: 274)$, including the metaphysics of morals. 
Up until the first edition of the Critique Kant's concern with synthetic $a$ priori judgements seems to be equally on both the negative argument about such judgements transgressing the bounds of sense and the positive argument about such judgements constituting the possibility of experience. Remarkably, there is a sharp decline in Kant's interest in a critique of traditional metaphysics after the A edition. Apart from some remarks (cf. $\ddot{U} E, 8: 226-5 \mathrm{I}$ ), he seems to consider the matter closed, and focuses instead on the constructive aspects of that future metaphysics that will be able to come forward as science, as the Prolegomena title reads in full. In the second Critique, Kant consciously or unconsciously but, in any case, incorrectly recalls the structure of the first Critique $(K p V, 5: 90)$. He even gives the impression that there is no chapter on the 'logic of illusion' (A6I/B86), called Dialectic. In the second Critique, there is indeed a chapter called the Dialectic of Pure Practical Reason. But this is only marginally concerned with a 'logic of illusion', i.e. the refutation of some misguided claims in moral philosophy. It is more concerned with the substantiation of positive claims about pure practical reason and its postulates.

Altogether, it seems that Kant, with the first publication of the first Critique, sees no further need to systematically critique traditional metaphysics, and instead argues for his own views on a metaphysics of nature and a metaphysics of morals, both of which must be built on synthetic principles a priori. In the B edition, Kant replaces the paragraph about the 'certain mystery' (AIо) quoted above with sections V and VI of the new introduction, which are in large part taken over from the Prolegomena. Here he argues for the claim that 'synthetic a priori judgments are contained as principles in all theoretical sciences of reason' (BI 4 ), and states that ' $\mathrm{t}$ ] $\mathrm{he}$ real problem of pure reason is now contained in the question: How are synthetic judgments a priori possible?' (BI9). This is the point where the Scheffner passage comes in.

The reviewer hinted at in this passage is the author of the so-called Göttingen Review of the first Critique. ${ }^{4}$ What Kant here calls the 'important problem of transcendental philosophy' is 'expressed with scholastic precision, the exact problem on which everything hinges ...: How are synthetic propositions a priori possible?' $(P, 4: 276)$, as he first formulates this in the Prolegomena. Kant addresses the first question of the Scheffner passage in the Groundwork under the title How is a Categorical Imperative Possible? and argues that the 'categorical ought represents a synthetic proposition a priori, since to my will affected by sensible desires there is added the idea of the same will but belonging to the world of the understanding - a will pure and practical of itself' $(G, 4: 454)$. 
Hence, the explanation of the categorical imperative, one of the central problems of Kant's critical metaphysics of morals, including a second Critique, relates to the problem of synthetic a priori judgements.

The parallel Kant sees between the theoretical and the practical problem of synthetic a priori propositions becomes even more striking when he comments on the How-is-a-categorical-imperative-possible passage as follows:

[T] his is roughly like the way in which concepts of the understanding, which by themselves signify nothing but lawful form in general, are added to intuitions of the world of sense and thereby make possible synthetic propositions a priori on which all cognition of a nature rests. $(G, 4: 454)$

So, the way in which 'the idea of freedom', or 'the idea of ... a will pure and practical of itself' $(G, 4: 454)$, gives rise to the moral law in imperatival form, i.e. a synthetic a priori proposition by which reason necessitates certain maxims, is 'roughly like' the way in which the categories give rise to principles by which the understanding determines appearances, or as Kant puts it in the Prolegomena, laws that the understanding prescribes to nature $(P, 4: 320)$.

Without going into the non-trivial details of this analogy, it is on this expanded basis of synthetic a priori propositions that we can make full sense of the dichotomy between the phenomenal and the noumenal that Kant first brought up in the Inaugural Dissertation but which now serves to capture an entirely novel configuration. 'The distinction of all objects in general into phenomena and noumena' (B294) no longer merely refers to the possibility of the former and the impossibility of the latter (noumena in a positive sense). Rather, on the basis of synthetic a priori propositions, cognition of the sensible world is now assigned to theoretical philosophy, whereas cognition of the intelligible world is assigned to moral philosophy. At the same time - and this is of great importance - it is only synthetic a priori propositions that require a critique. For it is only these propositions whose objective validity is problematic, and thus requires a non-empirical deduction. ${ }^{5}$ This becomes evident from section III of the Groundwork where the second Critique comes into focus. Under the title 'Autonomy of the Will as the Supreme Principle of Morality', Kant relates the notions of autonomy, the categorical imperative and the synthetic a priori to a prospective Critique of Practical Reason. 
First, he states, 'Autonomy of the will is the property of the will by which it is a law to itself' $(G, 4: 440)$.

Next, he gives the Formula of Autonomy, and the following comment. 'That this practical rule is an imperative ... cannot be proved by mere analysis of the concepts to be found in it, because it is a synthetic proposition; one would have to go beyond cognition of objects to a critique of the subject, that is, of pure practical reason' $(G, 4: 440)$.

Finally, he emphasizes the connection between the synthetic a priori character of the categorical imperative and the second Critique in the 'Division of All Possible Principles of Morality': 'That morality is no phantom ... requires a possible synthetic use of pure practical reason, which use, however, we cannot venture upon without prefacing it by a critique of this rational faculty itself' $(G, 4: 445)$.

In conclusion: the 'How-is-the-synthetic-a priori-possible?' question becomes the central question with the Scheffner-Nachla $\beta$ and the Prolegomena, and Kant literally transfers this insight to the B introduction of the Critique. He seems to be confident in putting this question front and centre with respect to the relevant sciences because he now sees that the answer to it is the key to the foundations of any science. In the Prolegomena he - for obvious reasons - confines himself to the speculative part of metaphysics, while the Groundwork makes the 'How-is-thesynthetic-a priori-possible?' question explicit in practical philosophy, for the first time in a published form.

So, why does the Scheffner-Nachlaß change the critical game? It marks Kant's important insight that the objective validity of any science depends on the objective validity of a number of laws, i.e. synthetic a priori propositions. This interpretation helps us understand the sense in which 'the substantive philosophical parallels between practical autonomy and theoretical legislation' (Watkins 20I9: 245) are grounded in Kant's discovery of the synthetic a priori character of any law, theoretical and practical. $^{6}$

\section{Notes}

I 'Nun ist die Frage wie ist ein categorischer Imperativ möglich wer diese Aufgabe auflöset der hat das echte princip der Moral gefunden. Der Rec: wird sich vermutlich eben so wenig daran wagen wie an das wichtige Problem der Transscendental philos. welches mit jenem der Moral eine auffallende Aehnlichkeit hat. Ich werde die Auflösung in Kurzem darlegen aber man darf hier nicht Idealismus und categorien besorgen.' On the implications of this note, see Pollok (200I: xi-xiv). 
2 Cf. G, 4: 4IO, $K p V, 5: 3,25$. Unless otherwise noted, passages from Kant's works are drawn from the Cambridge Edition of the Works of Immanuel Kant, ed. Paul Guyer and Allen Wood (Cambridge: Cambridge University Press, I992-). G = Groundwork of the Metaphysics of Morals; KpV = Critique of Practical Reason; $K U=$ Critique of the Power of Judgement, $P=$ Prolegomena VA-Prol = Vorarbeit to the Prolegomena .

3 I argue for this claim in chapter I.2.2 of Pollok (20I7).

4 On the impact of this review on Kant's philosophical development, see Pollok (200I: xxiii-xxxix).

5 For the connection between synthetic a priori propositions and the deduction of the categories, see $K U, 5: 288$.

6 A more detailed version of this interpretation can be found in part 3 ('The Legislation of Pure Reason') of Pollok (2017).

\section{References}

Pollok, Konstantin (200I) 'Einleitung'. In Konstantin Pollok (ed.), Immanuel Kant: Prolegomena zu einer jeden künftigen Metaphysik, die als Wissenschaft wird auftreten können (Hamburg: Meiner), pp. ix-lxii.

(2017) Kant's Theory of Normativity: Exploring the Space of Reason. Cambridge: Cambridge University Press.

Quine, W. V. O. (I990) Pursuit of Truth. Cambridge, MA: Harvard University Press.

Watkins, Eric (2019) Kant on Laws. Cambridge: Cambridge University Press. 